\title{
Aspectos clínico-patológicos e controle da paratuberculose em rebanho bovino leiteiro'
}

\author{
Elise M. Yamasaki ${ }^{2 *}$, Carlos H. Tokarnia ${ }^{3}$, Alexandre Galvão4, Marcos \\ J.P. Gomes ${ }^{5}$, José A.B. Chies ${ }^{6}$, Tiago Degani Veit 6 , Ana Paula Aragão ${ }^{4}$ \\ e Marilene F. Brito ${ }^{7}$
}

\begin{abstract}
Yamasaki E.M., Tokarnia C.H., Galvão A., Gomes M.J.P., Chies J.A.B., Veit T.D., Aragão A.P. \& Brito M.F. 2010 [Clinic-pathological aspects and control of paratuberculosis in a dairy cattle herd.] Aspectos clínico-patológicos e controle da paratuberculose em rebanho bovino leiteiro. Pesquisa Veterinária Brasileira 30(11):921932. Curso de Pós-Graduação em Medicina Veterinária, Universidade Federal Rural do Rio de Janeiro, Seropédica, RJ 23890-000, Brazil. E-mail: elise_my@ yahoo.com.br

Paratuberculosis (Johne's disease) is a granulomatous enteritis of ruminants caused by Mycobacterium avium subsp. paratuberculosis. Epidemiology, clinic-pathological and laboratorial aspects of paratuberculosis in a dairy cattle herd are described. The disease was diagnosed from 2006 to 2009 in eight cows that presented chronic-intermittent diarrhea and chronic weight loss, in the Rio Claro municipality, Rio de Janeiro. At necropsy, the subserosal lymphatic vessels were proeminent and dilated, mesenteric nodes were enlarged and intestinal mucosa was corrugated, thickened and of microgranular aspect. From duodenum to the rectum, histopathology revealed severe and diffuse granulomatous inflammation of the lamina propria and submucosa, broadened and distorted villi, dilatation of the lymphatic vessels in their apex, lymphangioectasia and granulomatous lymphangitis in the submucosa. Ziehl-Neelsen stain showed variable amounts of acid-fast bacilli in macrophages, in Langhans giant cells and freely in the mucosa and submucosa of the small intestine, colon and lymphnodes. In some cows, the lamina propria presented severe hypertrophy, mainly in the jejunum and ileum. Mycobacterium avium subsp. paratuberculosis was isolated through bacterial cultivation of samples taken from feces, intestinal mucosa and milk, and identified through IS900 PCR. From 298 cows older than three years, the percentage of reactive animals was $40 \%$ by indirect ELISA test. The diagnosis of paratuberculosis was based on clinic-epidemiological data, serology, bacterial isolation in Herrold egg yolk medium with micobactin and on IS900 PCR. After the adoption of control measures, as slaughter of cows with clinical signs, selective slaughter of seropositive cows, removal of the calf from the dam at birth, and use of the colostrum bank, we observed a reduction from six clinical cases to only one case per year, in the last three years of the study.
\end{abstract}

INDEX TERMS: Diseases of cattle, paratuberculosis, Mycobacterium avium subsp. paratuberculosis, diagnosis, control.

\footnotetext{
${ }^{1}$ Recebido em 29 de junho de 2010.

Aceito para publicação em 28 de julho de 2010.

2 Parte da Dissertação de Mestrado em Medicina Veterinária, Universidade Federal Rural do Rio de Janeiro (UFRRJ), BR $465 \mathrm{Km} \mathrm{7,}$ Seropédica, RJ 23890-000, Brazil. *Autor para correspondência: elise_my@yahoo.com.br

${ }^{3}$ Departamento de Nutrição Animal e Pastagem, Instituto de Zootecnia, UFRRJ, Seropédica, RJ.
}

\footnotetext{
${ }^{4}$ Doutorando em Ciências Veterinárias, UFRRJ, Seropédica, RJ.

${ }^{5}$ Laboratório de Bacteriologia Veterinária, Universidade Federal do Rio Grande do Sul (UFRGS), Av. Bento Gonçalves 9090, Bairro Agronomia, Porto Alegre, RS 91540-000, Brazil.

${ }^{6}$ Departamento de Genética, Instituto de Biociências, UFRGS, Av. Bento Gonçalves 9500, Campus do Vale, Porto Alegre, RS 91501-970, Brazil.

${ }^{7}$ Departamento de Epidemiologia e Saúde Pública, Instituto de Veterinária, UFRRJ, Seropédica, RJ.
} 
RESUMO.- A paratuberculose ou doença de Johne é uma enterite granulomatosa causada por Mycobacterium avium subsp. paratuberculosis. Descrevem-se os aspectos epidemiológicos, clínico-patológicos e laboratoriais da paratuberculose em rebanho bovino leiteiro no município de Rio Claro, região Sul do Estado do Rio de Janeiro. No período de 2006 a 2009, oito vacas adultas da raça Girolanda apresentaram diarreia crônico-intermitente e perda progressiva de peso. À necropsia, observaram-se linfonodos mesentéricos aumentados de volume e úmidos ao corte, vasos linfáticos subserosos das alças intestinais proeminentes, serosa do intestino com aspecto anelado e cerebroide e a mucosa espessada, pregueada e com aspecto microgranular. À microscopia havia, desde o duodeno até o reto, inflamação granulomatosa difusa, marcada dilatação dos vasos linfáticos no ápice das vilosidades, linfangiectasia e linfangite granulomatosa na submucosa, muscular e serosa. A inflamação granulomatosa também foi vista nos linfonodos mesentéricos. A coloração de Ziehl-Neelsen revelou variável quantidade de bacilos álcool-ácido resistentes no interior de macrófagos, de células gigantes de Langhans e livres na mucosa e submucosa dos intestinos delgado e grosso e em linfonodos mesentéricos. Em alguns animais, a lâmina própria da mucosa, principalmente do jejuno e íleo exibia acentuada hipertrofia. Mycobacterium avium subsp. paratuberculosis foi isolado em cultivo bacteriano de Herrold com micobactina, a partir de amostras de fezes, de raspado de mucosa intestinal e de leite e identificado pela técnica de PCR IS900. Através da avaliação sorológica semestral, foram analisadas 298 vacas do mesmo rebanho a partir de três anos de idade, observou-se cerca de $40 \%$ de animais reagentes ao teste ELISA indireto no período estudado. O diagnóstico da paratuberculose foi baseado nos dados clínico-patológicos, na sorologia, no isolamento e identificação do agente através de cultivo bacteriano e PCR IS900. Após implementação de medidas de controle, tais como eliminação de animais doentes, abate seletivo dos animais soropositivos, separação dos bezerros ao nascer e utilização de banco de colostro, observou-se, nos três anos de estudo, diminuição da ocorrência de casos clínicos no rebanho, de seis casos por ano para cerca de um caso por ano.

TERMOS DE INDEXAÇÃO: Doenças de bovinos, paratuberculose, Mycobacterium avium subsp. paratuberculosis, diagnóstico, controle.

\section{INTRODUÇÃO}

A paratuberculose ou doença de Johne é uma enterite infecciosa de natureza granulomatosa incurável, causada por uma bactéria álcool-ácido resistente (BAAR), Mycobacterium avium subsp. paratuberculosis (Map), que replica nos macrófagos da lâmina própria do intestino delgado e grosso. A doença caracteriza-se por diarreia crônica e intermitente, emagrecimento, queda da produção e da fertilidade e aumento da susceptibilidade a outras infecções. Bezerros com menos de 30 dias são os mais susceptíveis e os sinais clínicos começam a aparecer cerca de três anos após a infecção (Hagan 1938). Devido à lenta disseminação e ao caráter crônico, os prejuízos econômicos são mascarados pelas alterações secundárias à infecção por Map, como mastite, disfunções reprodutivas e diminuição da produtividade (Johnson-Ifearulundu \& Kaneene 1997). Os produtores que reconhecem a impossibilidade dos animais se recuperarem da diarreia, mesmo após tratamento, procuram abater o animal no intuito de evitar prejuízos na venda da carcaça; essa conduta mascara o problema, mantém a enfermidade sem diagnóstico no rebanho e ainda contribui para a disseminação da doença. Esta enfermidade tem importância considerável não só em relação aos prejuízos causados à indústria leiteira, mas também devido à possível participação do Map na doença de Crohn no homem, que se caracteriza por inflamação intestinal crônica principalmente no íleo, podendo afetar outras porções do trato digestivo (Chiodini 1989).

Os objetivos deste estudo foram constatar que a paratuberculose ocorre na região Sul-Fluminense, caracterizar os aspectos epidemiológicos, clínico-patológicos e laboratoriais da enfermidade no rebanho estudado, através do isolamento e identificação de Mycobacterium avium subsp. paratuberculosis em amostras de tecido intestinal, fezes e leite, através de cultivo bacteriano e PCR (Reação em Cadeia da Polimerase) IS900, bem como estimar a frequência de animais reagentes ao teste ELISA (enzyme-linked immunosorbent assays) para detecção de anticorpos contra o Map, através do monitoramento sorológico semestral do rebanho e implementar estratégias de controle da infecção visando reduzir a ocorrência de casos clínicos no rebanho no período estudado.

\section{MATERIAL E MÉTODOS}

\section{Histórico e sinais clínicos}

As informações sobre a doença no rebanho foram obtidas junto aos técnicos responsáveis pela propriedade situada no município de Rio Claro, região Sul do Estado do Rio de Janeiro.

\section{Controle.}

Durante os anos de 2006 a 2009, foram implementadas modificações no manejo e na alimentação dos animais, tais como: eliminação de animais com diarreia, abate seletivo de vacas que apresentavam altas concentrações de anticorpos no teste ELISA, que tinham mastite recidivante, problemas reprodutivos e ou idade avançada, separação dos bezerros das vacas logo após o nascimento e utilização de banco de colostro.

\section{Sorologia}

De 2006 a 2009 foram realizadas coletas sanguíneas semestrais de 298 vacas, a partir de três anos de idade, que totalizou 904 amostras. O sangue foi obtido por punção na veia coccígea; o material foi centrifugado e o soro acondicionado em tubos "Eppendorf", congelado a $-20^{\circ} \mathrm{C}$ e enviado ao Laboratório de Bacteriologia (LABACVET) da Universidade Federal do Rio Grande do Sul (UFRGS), local de realização do teste. Os soros foram processados para detecção de anticorpos contra Mycobacterium avium subsp. paratuberculosis, pelo teste ELISA indireto. 
Utilizou-se o antígeno protoplasmático (PPA-3) liofilizado extraído de Mycobacterium spp. (Allied Monitor). As placas de ELISA (Immulon 2HB) foram sensibilizadas com $50 \mu \mathrm{L}$ de antígeno $(10 \mathrm{mg} / \mathrm{ml})$ diluídos em $10 \mathrm{~mL}$ de tampão carbonato $0,05 \mathrm{M}, \mathrm{pH} 9,6$ e incubadas a $6^{\circ} \mathrm{C}$ por no mínimo 6 horas. Em seguida, foram lavadas com solução salina "tween" por três vezes. As amostras de soro foram diluídas e adsorvidas, a igual volume $(200 \mu \mathrm{L})$, em uma suspensão de $M$. phlei $(5 \mathrm{mg} /$ $\mathrm{mL}$ ) e permaneceram por 8 horas sob refrigeração. Após serem centrifugadas a $2000 \mathrm{rpm}$ por 3 minutos, $40 \mu \mathrm{L}$ do sobrenadante foram diluídos em $2 \mathrm{~mL}$ de PBS/tween80/gelatina (PBST $\left.{ }_{80} \mathrm{G}\right)$, resultando numa diluição final de 1:100. O soro adsorvido e diluído $(100 \mu \mathrm{L})$ foi colocado em cada poço da placa sensibilizada, em triplicata, e as placas foram incubadas por 1 hora a $6^{\circ} \mathrm{C}$. Em seguida, foram lavadas por três vezes com $\mathrm{PBST}_{80} \mathrm{G}$ a $6^{\circ} \mathrm{C}$ e secadas. Adicionou-se então, $100 \mu \mathrm{L}$ de conjugado anti-IgG bovino (Sigma) com peroxidase produzido em coelho, diluído a 1:20000 e colocado em cada poço da placa, incubando-as durante 1 hora sob refrigeração. Após esse tempo, as placas foram lavadas rapidamente com $\mathrm{PBST}_{80} \mathrm{G}$ por três vezes e $100 \mu \mathrm{L}$ de solução contendo tampão citrato $\mathrm{pH} 4(10 \mathrm{~mL}), 15 \mu \mathrm{L}$ de substrato ABTS ([2,2]azinobis[3ethyl]benzthiazolin sulfonic acid) e $35 \mu \mathrm{L}$ de $\mathrm{H}_{2} \mathrm{O}_{2}$, foram adicionados em cada poço e logo após incubadas a $20^{\circ} \mathrm{C}$ por cerca de 10 minutos. Finalmente, realizou-se a leitura em espectofotômetro, utilizando-se leitor de ELISA (Labsystems Multiskan MCC/340) com filtro 405nm; os valores das amostras foram considerados quando a densidade óptica do controle positivo atingiu $0,220+10 \%$, e o controle negativo 0,060 . A amostra foi considerada positiva quando a média das três densidades ópticas (DO) da amostra testada, dividida pela média dos três valores do controle negativo (índice ELISA), foi igual ou superior a 2,1, suspeito quando se obteve índice ELISA de 1,5 a 2,0 e negativo quando o valor foi de 1,0 a 1,4.

\section{Isolamento bacteriano}

Amostras fecais. De 2006 a 2008, realizaram-se quatro coletas de fezes (uma a cada semestre) totalizando 203 amostras de cerca de $100 \mathrm{~g}$ cada. As fezes foram coletadas diretamente da ampola retal, acondicionadas em recipientes plásticos com tampa, identificadas, refrigeradas e transportadas ao LABACVET da UFRGS, onde foram processadas para cultivo bacteriano em meio Herrold com micobactina. Após a homogenização, $1-2 \mathrm{~g}$ de fezes foram diluídas em $30 \mathrm{~mL}$ de água destilada estéril em um tubo cônico com tampa e submetidos à agitação por 30 minutos. Em seguida, adicionou-se $30 \mathrm{~mL}$ de cloreto de hexadecilpiridinio à 0,9\% (HPC, Sigma Chemical Co.) e foram colocadas novamente em agitação por 30 minutos e em descanso para sedimentação das partículas maiores por 15 minutos. Retirou-se $5 \mathrm{ml}$ do sobrenadante que foram colocados em outro recipiente e misturados a $30 \mathrm{ml}$ de HPC; após adequada homogenização manteve-se a mistura em temperatura de aproximadamente $21^{\circ} \mathrm{C}$ overnight. A solução foi submetida novamente à centrifugação por 20 minutos; o sobrenadante foi descartado e o sedimento foi misturado a $1 \mathrm{~mL}$ de antimicrobianos (vancomicina, neomicina e anfotericina). Meio de cultivo específico de Herrold com gema de ovo (HEYM, Herrold egg yolk medium) foi utilizado para proporcionar o crescimento da micobatéria (Stabel 1997). Utilizaram-se quatro tubos para cada amostra e em cada uma delas adicionouse $100 \mathrm{il}$ da mistura, sendo que em dois tubos adicionou-se micobatina J (Allied Monitor, Inc.). Os meios foram mantidos em estufa a $37^{\circ} \mathrm{C}$ por um período de 4-6 meses, sob observação quinzenal.

Para identificação do Map foi considerado o tempo de crescimento, a morfologia das colônias, coloração de Ziehl-Neelsen (ZN) e dependência à micobactina (Collins 1996, Manning \& Collins 2001). Para a caracterização molecular do Map, as colônias isoladas foram submetidas à PCR para amplificação da inserção genética IS900 específica do Map (Whittington et al. 1998).

Amostra de leite. Coletaram-se cerca de $100 \mathrm{~mL}$ de leite do tanque de armazenamento coletivo, obtido de quatro ordenhas consecutivas. A amostra foi acondicionada em recipiente de vidro estéril, refrigerada e enviada ao LABACVET da UFRGS, para isolamento do agente bacteriano. O processamento foi semelhante ao do cultivo bacteriano das amostras de fezes, com modificação na concentração do HPC, que foi utilizado a 0,7\% (Stabel 1997).

\section{PCR IS900}

Para caracterização molecular da espécie, as colônias isoladas foram submetidas à técnica de PCR IS900. Após exame visual dos meios de cultivo Herrold com micobactina, fez-se esfregaço das colônias morfologicamente compatíveis com Map e, em seguida, a coloração de ZN. As amostras positivas nesta coloração foram submetidas ao teste PCR IS900 no Laboratório de Genética da UFRGS. Em "eppendorf" uma a duas colônias foram diluídas em $50 \mu \mathrm{L}$ de água destilada estéril e colocadas em banho maria a $100^{\circ} \mathrm{C}$, por 20 minutos. Utilizouse o seguinte protocolo: tampão de PCR 1x; 10pmol de cada primer do IS900 do Map P90 (5'-GAAGGGTGTTCGGGGCCG TCGCTTAGG) e P91 (5'-GGCGTTGAGGTCG ATCGCCCAC GTGAC); 0,4mM de cada dNTP; $1,5 \mathrm{mM}$ de $\mathrm{MgCl}_{2}$ e $1 \mathrm{Ul}$ de taq polimerase. A amplificação foi realizada em tubos de $550 \mu \mathrm{L}$ em termociclador com 96 lugares sob as seguintes condições: desnaturação inicial de $94^{\circ} \mathrm{C}$ por 5 minutos, 35 ciclos compostos dos passos de desnaturação a $94^{\circ} \mathrm{C}$ por 30 segundos, anelamento a $62^{\circ} \mathrm{C}$ por 15 segundos, extensão a $72^{\circ} \mathrm{C}$ por 1 minuto e extensão final de 5 minutos. Os produtos de aproximadamente $400 \mathrm{pb}$, foram analisados e avaliados pela eletroforese a $100 \mathrm{~V}$ em gel de agarose 1,5\% corado com brometo de etídeo, segundo a técnica descrita por Whittington et al. (1998), com modificações. Para controle positivo e negativo foram utilizadas uma cepa referência de Map e outra de Mycobacterium bovis, respectivamente, do LABACVET/UFRGS.

\section{Necropsia e histopatologia}

Nos três anos de estudo, 15 animais com ou sem sintomatologia de paratuberculose foram necropsiados na fazenda em estudo. Alguns deles morreram naturalmente e outros foram submetidos à eutanasia conforme prescrição das normas de bem estar animal (COBEA 1979). Durante as necropsias foram avaliados e coletados fragmentos de diversos órgãos, as amostras foram fixadas em solução de formol a 10\% tamponada com carbonato de cálcio. Em recipientes separados e identificados, fragmentos de diferentes porções do trato intestinal e de linfonodos mesentéricos foram coletados. O processamento dos tecidos foi realizado pelos métodos usuais para exame histológico, embebidas e incluídas em parafina, cortadas a $5 \mu$ e coradas pela hematoxilina-eosina ( $\mathrm{HE})$. Cortes de todas as secções de intestino delgado e grosso, linfonodos mesentéricos e outros órgãos que apresentaram infiltrado inflamatório granulomatoso foram corados pela técnica de Ziehl-Neelsen. 


\begin{tabular}{|c|c|c|c|c|c|}
\hline $\begin{array}{l}\text { Identificação } \\
\text { do animal }\end{array}$ & Idade & $\begin{array}{c}\text { Data da } \\
\text { necropsia }\end{array}$ & $\begin{array}{l}\text { Intensidade das lesões } \\
\text { Intestinais à necropsia } \\
\text { e histopatologia }\end{array}$ & $\begin{array}{c}\text { Exames } \\
\text { laboratoriais } \\
\text { positivos }\end{array}$ & SAPC \\
\hline 493 & 6 anos & 19.04 .2006 & +++ & Histopatologia & 30802 \\
\hline 507 & 6 anos & 23.05 .2006 & +++ & Histopatologia & $30810-30813$ \\
\hline 498 & 6 anos & 06.07 .2006 & +++ & Histopatologia & $30819-30821$ \\
\hline 174 & & Não necropsiadob & +++ & $\begin{array}{l}\text { Histopatologia } \\
\text { ELISA } \\
\text { Cultivo fecal } \\
\text { PCR IS900 }\end{array}$ & 30908 \\
\hline 295 & 5 anos & 22.12 .2007 & +++ & $\begin{array}{l}\text { Histopatologia } \\
\text { ELISA } \\
\text { Cultivo fecal } \\
\text { PCR IS900 }\end{array}$ & $31138-31147$ \\
\hline 500 & 8 anos & 09.09 .2008 & ++ & $\begin{array}{l}\text { Histopatologia } \\
\text { ELISA } \\
\text { Cultivo fecal } \\
\text { PCR IS900 }\end{array}$ & $31596-31604$ \\
\hline 190 & 7 anos & 31.08 .2008 & + & $\begin{array}{l}\text { Histopatologia } \\
\text { ELISA }\end{array}$ & 31588-31595 \\
\hline 335 & 5 anos & 20.04. 2009 & +++ & $\begin{array}{c}\text { Histopatologia } \\
\text { ELISA }\end{array}$ & $31774-31781$ \\
\hline
\end{tabular}

a +++ Lesões acentuadas, ++ moderadas, + leves.

b Material recebido para histopatologia.

c SAP = Registro do exame histopatológico no Setor de Anatomia Patológica, Projeto Sanidade Animal Embrapa/UFRRJ.

\section{RESULTADOS}

\section{Histórico}

Para a formação do rebanho da propriedade estudada, bovinos da raça Girolanda foram trazidos do município de Resende, Estado do Rio de Janeiro. Segundo informações, desde 2005 até a ocasião da primeira visita à propriedade, no início de 2006, cerca de sete vacas haviam apresentado quadro de emagrecimento progressivo, diarreia crônica não responsiva às terapias antidiarreicas convencionais $e$ morreram naturalmente. A partir de 2006, dentre as 15 vacas necropsiadas, sete apresentaram quadro clínico sugestivo de paratuberculose, acompanhado de mastite recidivante, distúrbios reprodutivos ou idade avançada e baixa produtividade (Quadro 1). Todos os animais acometidos eram vacas adultas, crias da fazenda, em fase de lactação ou secas. O veterinário responsável informou que nos exames de tuberculinização com teste cervical comparativo, realizados no rebanho, havia acentuada reação positiva para a tuberculina aviária.

\section{Sinais clínicos}

Em geral, os animais apresentavam emagrecimento progressivo, estado nutricional regular a ruim, apatia, diminuição e até parada da produção de leite, diarreia crônica profusa e intermitente, inicialmente verde-oliva, depois amarronzada a enegrecida, eliminada muitas vezes sob forma de jatos (Fig.1). Muco e estrias de sangue, eventualmente, eram observados nas fezes. Problemas reprodu- tivos e mastite recidivante, eram as complicações mais frequentes desse rebanho.

\section{Controle}

Em 2006, após abate dos animais que já apresentavam diarreia, ocorreram mais dois casos clínicos de paratuberculose no rebanho. Em 2007, 2008 e 2009 observou-se uma vaca com diarreia a cada ano. Nos três anos de estudo, notou-se considerável diminuição de animais com sinais clínicos no rebanho, de seis casos clínicos

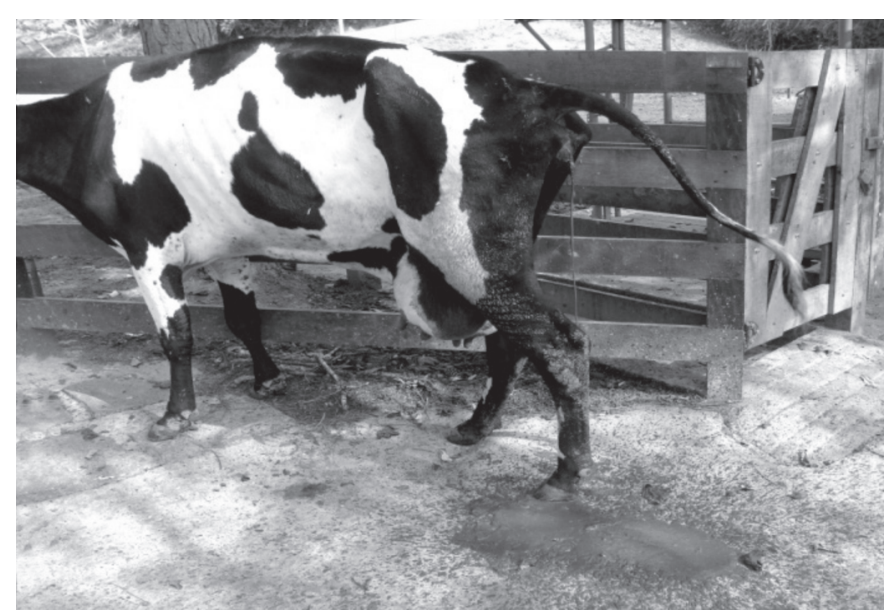

Fig.1. Vaca 498, com paratuberculose no município de Rio Claro, RJ. Animal magro com diarreia profusa eliminada sob forma de jato. 
a cada ano para cerca de um caso clínico por ano. Nesse período foram abatidas aproximadamente 60 vacas que apresentavam altos índices de anticorpos no teste ELISA, mastite recidivante, problemas reprodutivos e ou idade avançada.

\section{Isolamento bacteriano}

Dentre as 203 amostras de fezes submetidas ao isolamento bacteriano em meio Herrold com micobactina, 14 amostras (7\%) apresentaram colônias com características compatíveis com Map (Fig.2), tais como crescimento lento, coloração álcool-ácido resistente (Fig.3) e dependência à micobactina. As amostras de raspado de mucosa intestinal (Vaca 174) e leite, processadas para cultivo bacteriano, igualmente apresentaram colônias compatíveis. Nas demais amostras não houve crescimento do agente após 24 semanas de incubação, e ou, a contaminação inviabilizou a visualização de colônias típicas.

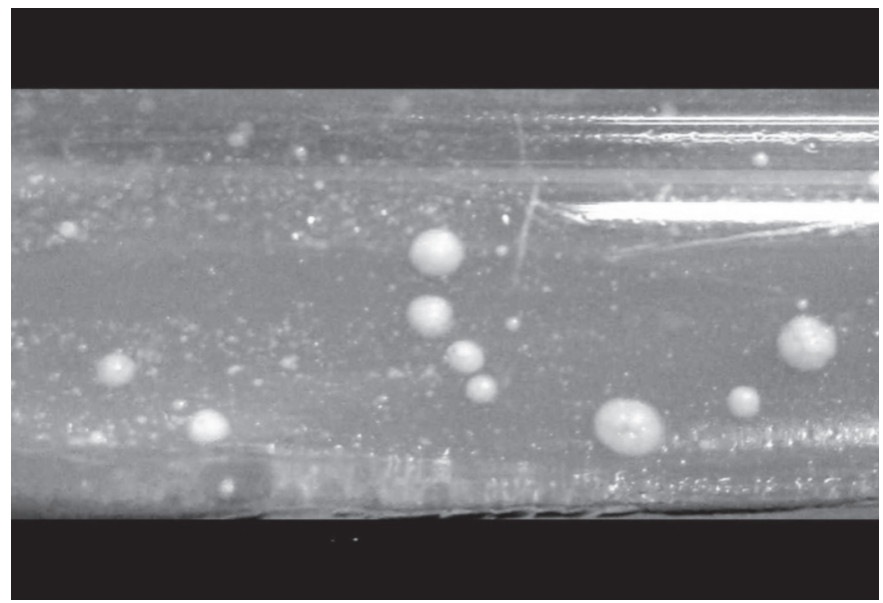

Fig.2. Colônias bacterianas de Mycobacterium avium subsp. paratuberculosis, isoladas em meio Herrold com micobactina, de amostra fecal da Vaca 174, no município de Rio Claro, RJ.

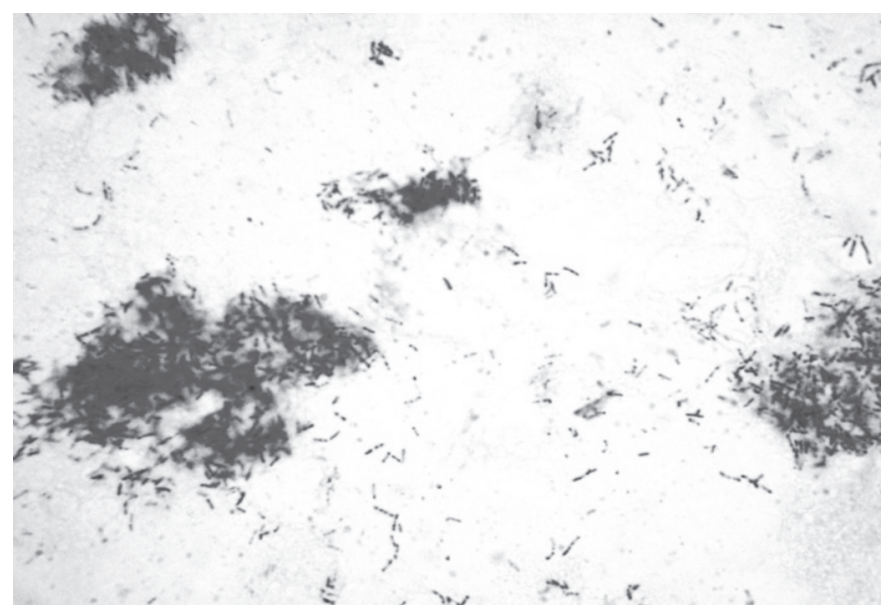

Fig.3. Esfregaço das colônias bacterianas isoladas em meio Herrold a partir de amostras de fezes, evidenciando bacilos álcool ácido resistentes, da Vaca 500 com paratuberculose, no município de Rio Claro, RJ. Ziehl-Neelsen, obj.100x.

\section{PCR IS900}

Das 15 amostras (14 de fezes e uma de leite) isoladas em HEYM com micobactina compatíveis com Map, cinco (quatro de fezes e uma de leite) apresentaram amplificação do material genético no teste PCR IS900. Colônias isoladas de amostras de leite do tanque coletivo e de fezes das vacas 174, 295, 491 e 500 foram positivas; já amostras oriundas de fezes das vacas $0185,242,230,245,298,352,509$, 518,568 e 1247, apesar de serem morfologicamente compatíveis com Map foram negativas no referido teste.

\section{ELISA}

De 2006 a 2009, foi feita avaliação anual pelo teste ELISA indireto e observou-se aproximadamente $40 \%$ de vacas reagentes. Os dados obtidos constam na Figura 4.

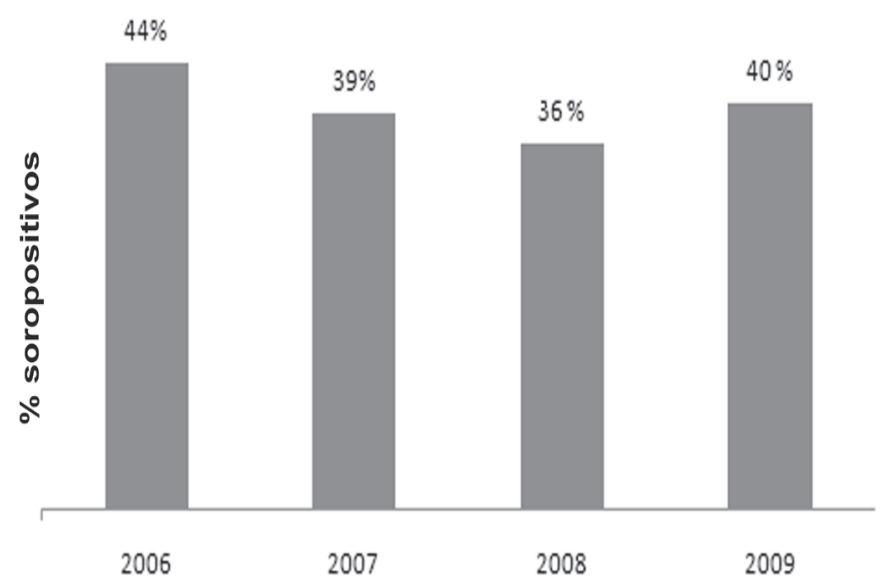

Fig.4. Frequência de vacas reagentes ao teste ELISA em rebanho leiteiro com paratuberculose, no município de Rio Claro, RJ, nos anos de 2006-2009.

\section{Achados de necropsia}

De 15 vacas necropsiadas na propriedade, sete apresentaram evidências macroscópicas de paratuberculose (Quadro 1). Os outros animais necropsiados morreram por diversas causas, tais como, queda de barrancos, edema maligno, fratura de membro, atolamento, abscesso hepáti$\mathrm{co}$, entre outros, e não foram observadas lesões macro e microscópicas compatíveis com paratuberculose. Os principais achados foram:

Vasos linfáticos. Os vasos linfáticos mesentéricos estavam evidentes, esbranquiçados, por vezes tortuosos com aspecto varicoso, sob a serosa das alças intestinais (Fig.5).

Linfonodos mesentéricos. Em geral, apresentavam acentuado aumento de volume, úmidos protraídos ao corte, com áreas multinodulares irregulares e brancacentas na região cortical e medular (Fig.6) e com acúmulo de líquido de aspecto leitoso no seio medular.

Intestino delgado. A serosa estava espessada com aspecto anelado e/ou cerebroide. À abertura, o duodeno das Vacas 493 e 507 apresentava a mucosa espessada, enrugada com superfície irregularmente avermelhada e havia nodulações com aspecto polipoide (Fig.7 e 11). O 

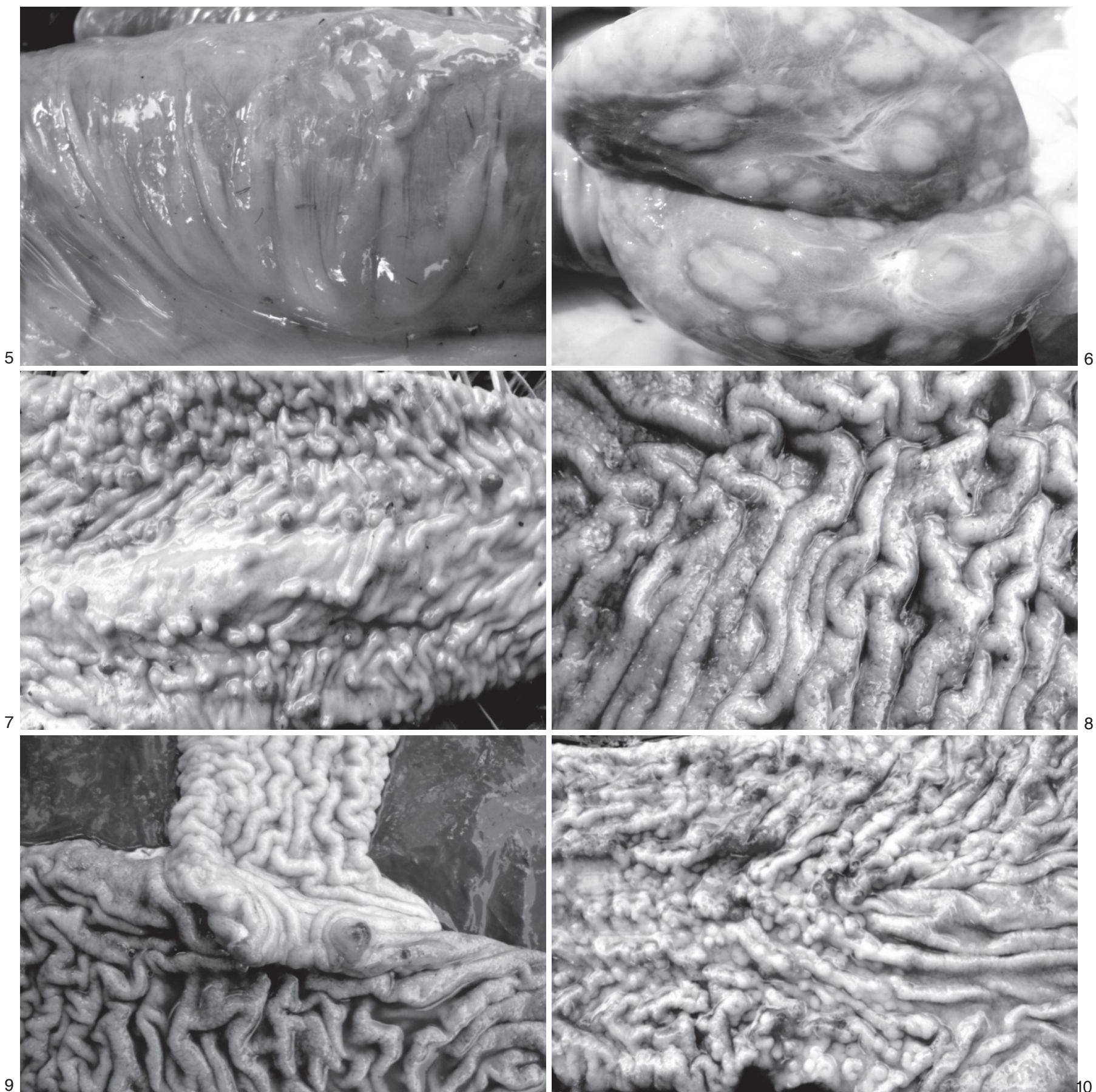

Fig.5. Alça intestinal com vasos linfáticos subserosos espessados, esbranquiçados e tortuosos (aspecto varicoso) na paratuberculose em rebanho bovino leiteiro, no município de Rio Claro, RJ. (Vaca 335)

Fig.7. Mucosa duodenal espessada, avermelhada, com aspecto enrugado e com projecões polipoides na Vaca 493 com paratuberculose.

Fig.9. Válvula íleo-cecal com nódulos hemorrágicos; tecidos adjacentes (íleo terminal e ceco) espessados com aspecto microgranular, na Vaca 335 com paratuberculose.

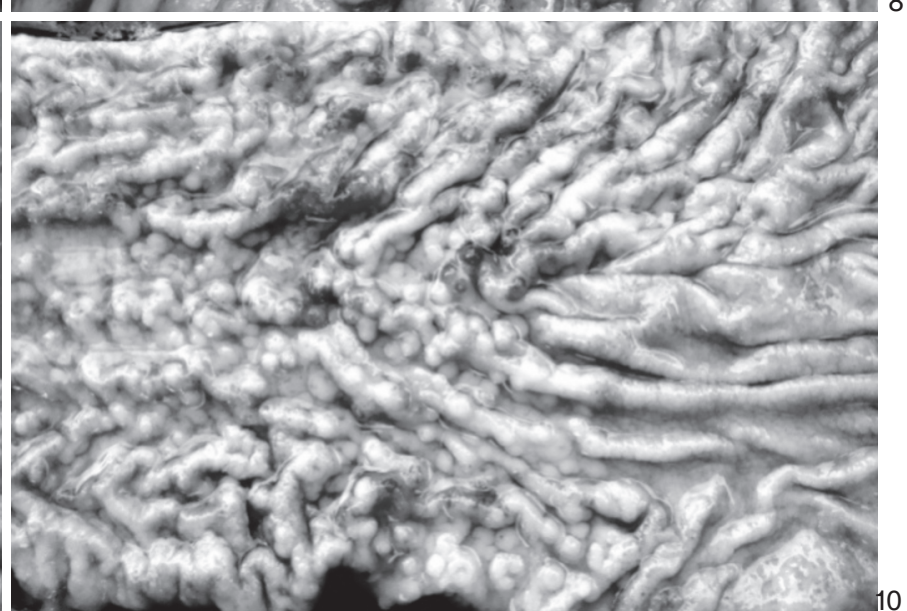

Fig.6. Linfonodo mesentérico tumefeito, ao corte com áreas claras protruídas na Vaca 498 com paratuberculose.

Fig.8. Mucosa de íleo espessada com áreas avermelhadas, pregueadas e com aspecto granular, na Vaca $335 \mathrm{com}$ paratuberculose.

Fig.10. Cólon distal espessado com evidente pregueamento da mucosa, projeções papiliformes e áreas avermelhadas irregulares, na Vaca $335 \mathrm{com}$ paratuberculose. 
jejuno e o íleo exibiam, igualmente, a mucosa espessada, enrugada, com áreas avermelhadas e com aspecto finamente granular (Vacas 295, 335, 498 e 507) (Fig.8); na

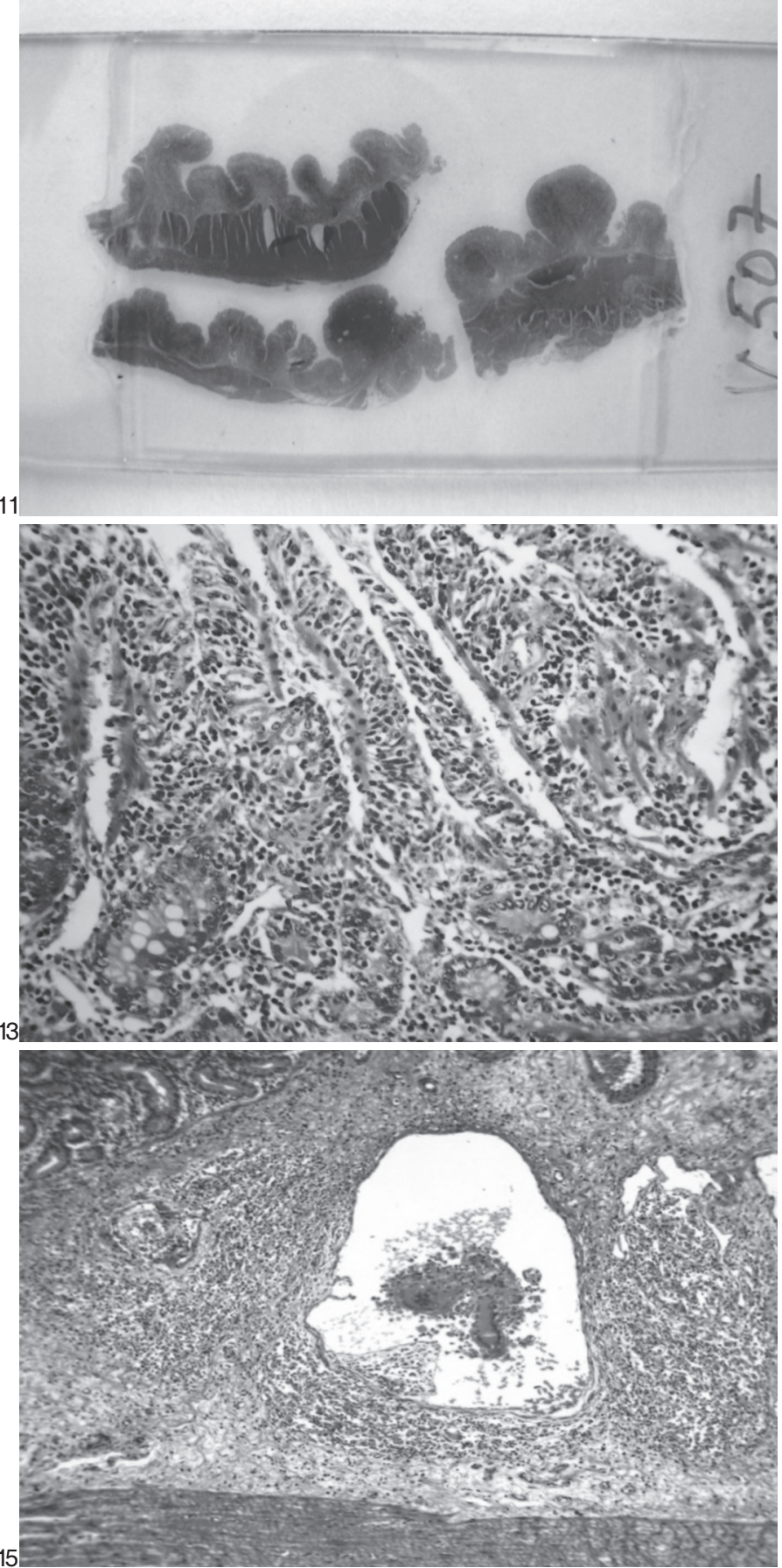

Fig.11. Aspecto polipoide da mucosa do duodeno da Vaca 507 com paratuberculose. Lâmina corada com HE.

Fig.13. Infiltrado mononuclear e hipertrofia das fibras musculares da lâmina própria da mucosa do jejuno, da Vaca 500 com paratuberculose. HE, obj.16x.

Fig.15. Ectasia, perilinfangite e endolinfangite granulomatosa com células gigantes em vaso linfático da submucosa de íleo, na Vaca 174 com paratuberculose. HE, obj.10x. maioria dos animais, essas lesões intensificavam-se do terço final do jejuno até o final do íleo. Nas Vacas 335, 498, 500 e 507 as placas de Peyer estavam evidentes e
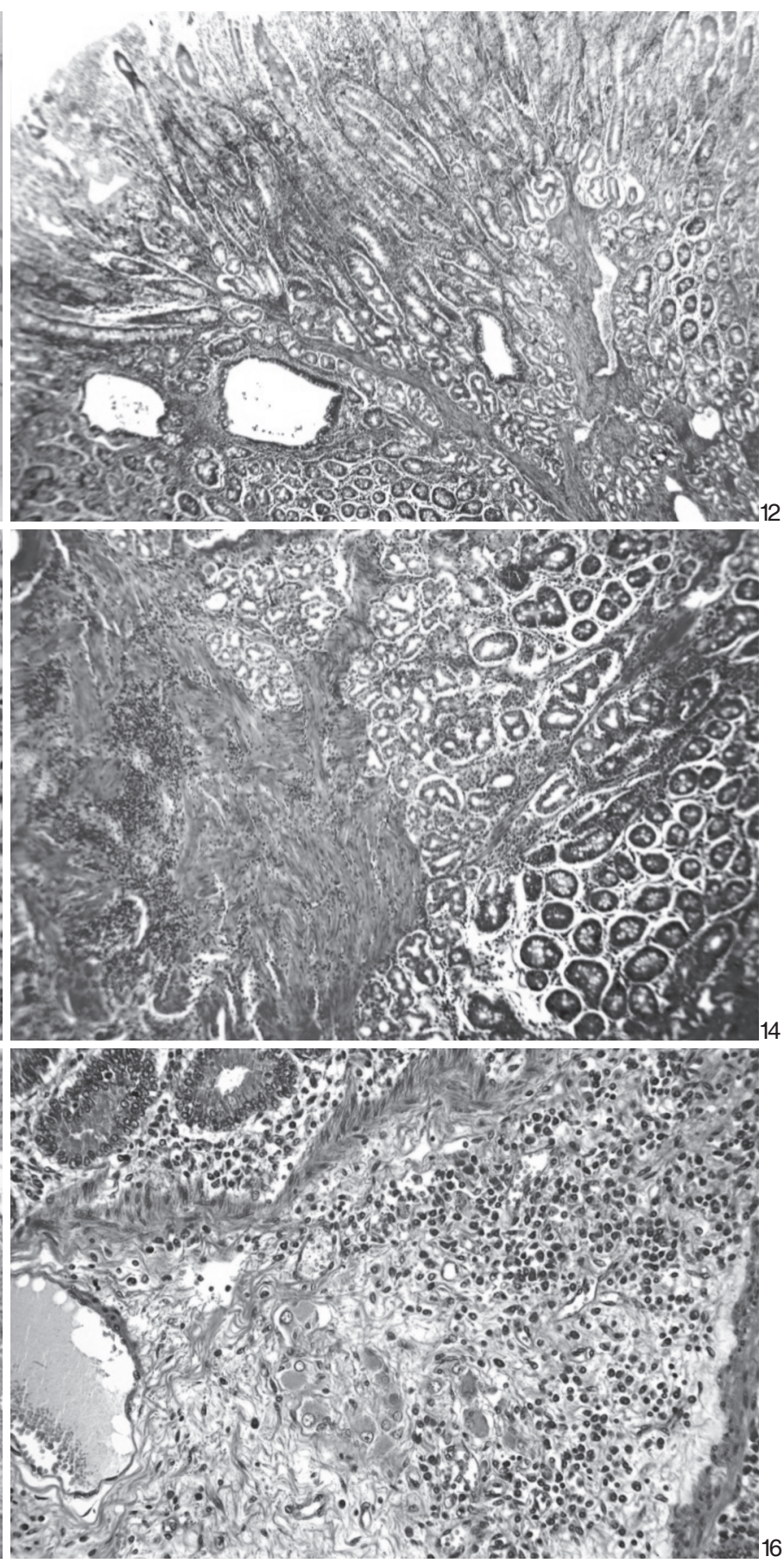

Fig.12. Aspecto 'arboriforme', dilatação de criptas e hipertrofia da lâmina própria da mucosa do duodeno, na Vaca 507 com paratuberculose. HE, obj.10x.

Fig.14. Hipertrofia da muscular da mucosa de duodeno com infiltração mononuclear, na Vaca 507 com paratuberculose. HE, obj.10x.

Fig.16. Infiltração inflamatória mononuclear na submucosa do íleo com proliferação fibroblástica ao redor dos plexos de Meissner, na Vaca 174 com paratuberculose. HE, obj.25x. 
salientes e exibiam aspecto de fitas. O conteúdo do intestino delgado era líquido e a coloração variava desde amarelado a verde-oliva claro, até marrom escuro.

Intestino grosso. A válvula íleo-cecal em geral estava edemaciada, com a mucosa espessada, de aspecto granular (Vacas 295 e 335), avermelhada (Vaca 190) ou com nódulos hemorrágicos (Vacas 295, 335 e 498) (Fig.9). O ceco apresentava-se dilatado, com a mucosa espessada com áreas avermelhadas e superfície granular, o que conferia um aspecto pavimentoso (Vacas 498, 295 e 335) (Fig.9). O conteúdo era semi-líquido a líquido, em geral de cor verde-oliva. A mucosa do cólon exibia acentuado espessamento, pregueamento (Vacas 295 e 335), nodulações (Vaca 335) (Fig.10), áreas avermelhadas e aspecto granular (Vacas 493, 295 e 335). O conteúdo variava de pastoso a líquido verde-oliva escuro. O reto igualmente apresentava-se espessado, com aspecto granular e com áreas avermelhadas irregulares na mucosa (Vacas 295 e 335) e conteúdo semi-líquido a líquido.

Demais órgãos. Os linfonodos superficiais e de outras vísceras, por vezes estavam aumentados de tamanho e, na maioria dos casos, o aspecto macroscópico acompanhava o descrito para os linfonodos mesentéricos. No coração da Vaca 500, havia no endocárdio, abaixo da válvula semilunar aórtica, áreas esbranquiçadas, sob forma de placas irregulares e a íntima da aorta abdominal com a superfície irregular, rugosa, firme e esbranquiçada.

\section{Alterações histológicas}

Os achados histológicos mais importantes foram observados no intestino e nos linfonodos mesentéricos. As lesões foram semelhantes entre os animais necropsiados e entre as seções do intestino avaliadas e diferiram apenas em intensidade (Quadro 1).

Linfonodos mesentéricos. Nos seios subcapsulares e na região medular observou-se infiltrado inflamatório granulomatoso rico em macrófagos epitelioides e em células gigantes do tipo Langhans; por vezes havia eosinófilos; proliferação fibroblástica e de vasos linfáticos nos seios medulares. Verificou-se variação na densidade de BAAR no interior de macrófagos e de células gigantes de Langhans entre os diversos linfonodos avaliados e entre os animais necropsiados.

Intestino delgado. Na mucosa desde o duodeno até o íleo observaram-se infiltração linfoplasmocitária, macrófagos epitelioides e células gigantes de Langhans e numerosos BAAR foram evidenciados pelo ZN. Em variadas áreas havia marcada dilatação dos vasos linfáticos, especialmente no ápice das vilosidades. No lúmen de algumas criptas dilatadas havia neutrófilos e debris celulares. Os folículos linfóides das placas de Peyer, por vezes, apresentavam infiltração inflamatória granulomatosa. Observou-se ainda, hipertrofia de fibras musculares lisas da lâmina própria, principalmente em jejuno (Fig.13) e íleo. A muscular da mucosa também apresentou áreas de hipertrofia, por vezes acompanhadas de infiltração inflamatória granulomatosa por entre as fibras musculares (Fig.14). As lesões polipoides ob- servadas no duodeno correspondiam à marcada hipertrofia da muscular da mucosa, à hipertrofia da lâmina própria e à hiperplasia de glândulas duodenais, o que conferia um aspecto "arboriforme" à mucosa (Fig.12). Na submucosa, em geral, do jejuno e íleo, observaram-se proliferação fibroblástica, congestão, perivasculite, leucocitostase, linfangiectasia, perilinfangite e linfangite granulomatosa; muitas vezes havia macrófagos epitelioides e células gigantes de Langhans ocluindo total ou parcialmente o lúmen de vasos linfáticos (endolinfangite) (Fig.15). Foi observada perineurite dos plexos de Meissner que, por extensão da lesão, apresentavam-se envoltos por fibrose e inflamação da mesma natureza (Fig.16). A camada muscular, por vezes, apresentou fibrose focal e infiltrado inflamatório com macrófagos e células gigantes entre os feixes de fibras musculares e ao redor dos plexos nervosos de Auerbach (perineurite) (Fig.17), além de linfangiectasia e linfangite. Essas alterações também foram observadas na serosa, com maior intensidade nos casos mais severos (Fig.18).

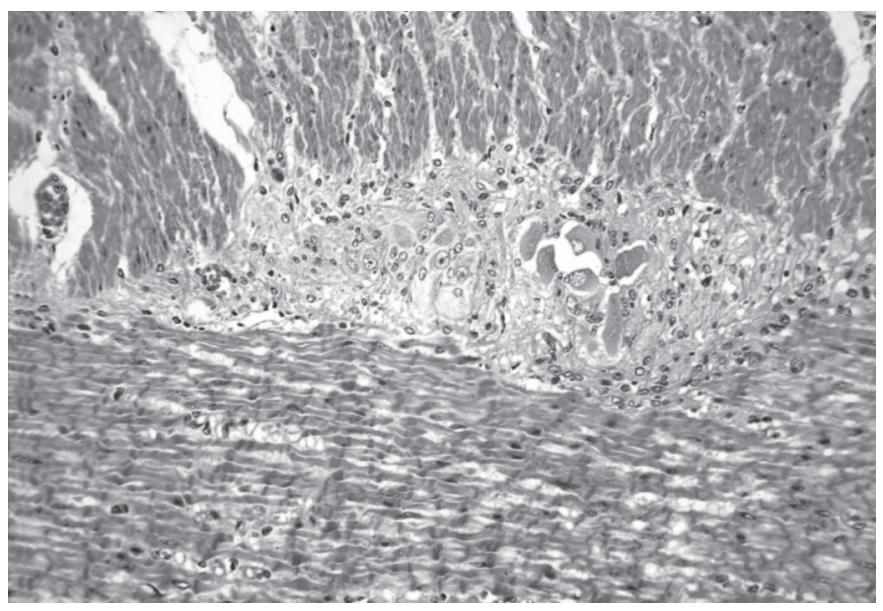

Fig.17. Plexo nervoso de Auerbach envolto por fibrose e infiltrado inflamatório granulomatoso na camada muscular do íleo, na Vaca 174 com paratuberculose. HE, obj.16x.

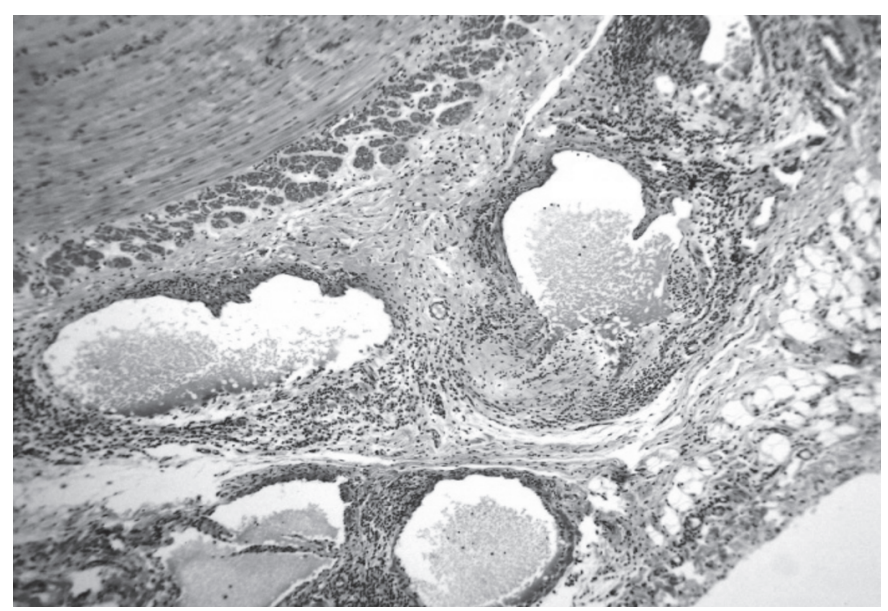

Fig.18. Serosa do íleo com ectasia de vasos linfáticos e perilinfangite mononuclear na Vaca 335 com paratuberculose. HE, obj.10x. 
Intestino grosso. As mucosas da válvula íleo-cecal, ceco, cólon e reto apresentaram congestão, infiltração inflamatória mononuclear rica em macrófagos epitelioides e variável quantidade de BAAR observados pela coloração de ZN. Na muscular da mucosa do ceco, cólon e reto observaram-se áreas de espessamento e infiltrado inflamatório mononuclear multifocal. Na submucosa do ceco, cólon e reto observaram-se dilatação dos vasos linfáticos, infiltração por células linfoplasmocitárias, macrófagos e células gigantes de Langhans e proliferação fibroblástica. Na camada muscular do cólon havia infiltração granulomatosa entre os feixes musculares. Na serosa do cólon, por vezes, havia dilatação dos vasos linfáticos com infiltração mononuclear.

\section{DISCUSSÃO}

\section{Histórico e sinais clínicos.}

O rebanho era proveniente de Resende, RJ, local onde já havia descrição de casos clínicos da enfermidade (Ferreira et al. 2003). É provável que os animais foram adquiridos já infectados para a formação do rebanho. Em três anos de estudo, um dos resultados mais importantes foi a redução do número de animais com sinais clínicos da paratuberculose, de seis casos clínicos por ano para um caso a cada ano. A partir desta observação, supõe-se que a eliminação de animais com diarreia proporcionou um ambiente com menor carga de Map, o que provavelmente, minimizou as possibilidades de infecção de novos animais. Na paratuberculose, as fezes se apresentam tipicamente homogêneas, não hemorrágicas e sem muco (Buergelt et al. 1978, Clarke 1997), esses aspectos foram comumente observados nos animais da propriedade estudada. A diarreia e o emagrecimento são os sinais clínicos mais característicos dessa enfermidade em bovinos (Whitlock \& Buergelt 1996) e ocorrem como consequência da infiltração inflamatória granulomatosa no intestino que provoca má absorção de nutrientes e perda progressiva de peso sem, no entanto, interferir no apetite dos animais. Todos esses sinais estiveram presentes nos animais deste estudo. É importante ressaltar que, apesar do clássico para a enfermidade ser de animais magros, algumas vacas apresentavam escore corporal regular, o apetite mantinha-se normal, apresentavam diarreia intermitente e, à necropsia, as lesões eram características da doença, como o que ocorreu em quatro animais por nós estudados (Vacas 493, 507, 190 e 500).

\section{Isolamento bacteriano}

O baixo número de amostras fecais, das quais foi possível isolar o agente bacteriano, pode estar associado a fatores como a eliminação intermitente do patógeno pelas fezes, a não adaptação da cepa ao meio de cultivo e baixa sensibilidade da técnica (Whitlock \& Buergelt 1996). As técnicas de cultivo fecal possuem algumas desvantagens tais como a necessidade de cuidados especiais, desde a coleta das amostras até a colocação do inóculo no meio, incluindo a alta qualidade de controle do meio, bem como o prolongado tempo de incubação (aproximadamente 16 semanas) e o alto custo (Whitlock et al. 2000). O isola- mento do Map na amostra de leite provavelmente está relacionado à higienização inadequada no momento da ordenha, fato que possivelmente causou a contaminação do leite estocado no tanque, do qual a amostra foi coletada. Deve-se levar em consideração que Ayele et al. (2005) demonstraram que vacas subclínicas podem eliminar Map através do leite, cuja micobactéria pode ocasionalmente sobreviver à pasteurização. Carvalho (2008) também detectou o Map a partir de técnicas moleculares, em amostra de leite oriunda de uma vaca com sinais clínicos da paratuberculose. A importância deste achado se justifica não só no possível papel do Map no desencadeamento da doença de Crohn em seres humanos (Hermon-Taylor \& Bull 2002), mas também na infecção de novos bezerros e manutenção da doença no rebanho (Sweeney 1996).

\section{PCR IS900}

Das amostras submetidas ao PCR IS900, 29\% apresentaram amplificação do material genético. Técnicas do protocolo adotado podem ter interferido na amplificação e na identificação do material genético. Em estudo realizado por Whittington et al. (1998), algumas colônias provenientes de cultivo bacteriano apresentaram-se negativas quando analisadas num primeiro momento; no entanto, resultaram positivas quando reanalisadas após tratamentos com substâncias distintas, as quais possivelmente minimizaram os efeitos inibitórios para a amplificação da cadeia de DNA. Em nosso estudo, as colônias não foram submetidas à segunda análise de PCR, o que poderia ter elevado a percentagem de amostras positivas.

\section{ELISA e o controle da enfermidade}

A alta porcentagem de animais reagentes ao teste ELISA encontrados neste estudo (cerca de $40 \%$ do rebanho), foi semelhante ao descrito no Mato Grosso (Rivera 1996), em São Paulo (Fonseca et al. 2000), no Rio de Janeiro (Ferreira et al. 2001), no Rio Grande do Sul (Gomes et al. 2002) e em Pernambuco (Mota et al. 2007). Estes animais representam uma das categorias mais importantes no controle da enfermidade, pois além de não apresentarem os sinais clínicos, eliminam intermitentemente o agente no ambiente e mantêm a infecção no rebanho (Chiodini et al. 1984). Em contrapartida, pesquisadores afirmam que alguns animais, quando expostos ao Map, desenvolvem uma resposta imune protetora que destrói o microrganismo e torna o animal positivo no teste sorológico (Chiodini et al. 1984). Com repetidas exposições ao antígeno, tais animais resistentes e não infectados permanecem reagentes ao teste; estes indivíduos poderiam ser selecionados e não abatidos. No entanto, há dificuldades em se diferenciar animais resistentes de infectados, através de testes imunológicos, pois estes informam o status de exposição e não de infecção; a presença de animais reagentes não necessariamente significa que o rebanho está infectado (Chiodini et al. 1984). Estima-se que num rebanho, para cada caso clínico de paratuberculose existem de 15 a 25 animais subclínicos (Sweeney 1996). Nestes três anos de estudo, ocorreram sete casos clínicos 
na propriedade e cerca de $40 \%$ das vacas foram reagentes ao teste ELISA. Esse índice se aproxima das estimativas descritas na literatura, entre o número de animais com sinais clínicos e o de subclínicos em um rebanho infectado com Map. Deve-se ainda, considerar a possibilidade dos animais subclínicos apresentarem baixas concentrações de anticorpos e resultarem em sorologia negativa; neste caso, possivelmente, a taxa de infecção seria maior (Collins 1996). É importante ressaltar que os testes para diagnóstico sorológico da paratuberculose podem fornecer resultados falsopositivos devido a reações cruzadas com tuberculose bovina e aviária, Mycobacterium spp., Actinomyces sp., Dermatophilus spp., Nocardia spp., Streptomyces spp., Escheria coli e Corynebacterium sp. (Chiodini et al. 1984). A variação observada no teste ELISA entre 2006 e 2009 retrata a dificuldade em se estabelecer o diagnóstico num estágio pré-clínico. A melhor maneira de se definir um animal livre da enfermidade deveria ser baseada na ausência de infecção no rebanho de origem. Embora as medidas de controle implantadas no rebanho estudado já tenham surtido um efeito positivo em relação à diminuição do número de casos clínicos, um período de três anos é insuficiente para obter um perfil de rebanho controlado para paratuberculose. Uma propriedade deve apresentar múltiplos testes anuais negativos de todos os indivíduos adultos, para ter seu rebanho considerado livre de paratuberculose, assim como execução de práticas de manejo e prevenção na introdução de animais infectados com Map no rebanho (Collins et al. 2005). No entanto, devido à natureza insidiosa da doença e liberação intermitente do microrganismo no ambiente, geralmente não é possível eliminar o Map do rebanho (Sherman 1985).

\section{Necropsia e histopatologia.}

O espessamento e o aspecto tortuoso ("varicoso") dos vasos linfáticos, visualizados à necropsia desde o mesentério até a serosa das alças intestinais, nos casos mais severos, se devem à marcada linfangiectasia, perilinfangite, linfangite e endolinfangite granulomatosas, por vezes oclusiva, observados ao exame histológico. Esses achados foram frequentes em nossos animais e já descritos por outros pesquisadores (Buergelt et al. 1978, Clarke 1997). A linfangite é um achado comum e pode ser considerada uma característica macroscópica presuntiva do diagnóstico da paratuberculose, à necropsia (Driemeier et al. 1999, Jubb et al. 2007). A linfadenite mesentérica granulomatosa rica em macrófagos epitelioides e células gigantes, com presença de BAAR, comumente observados em animais deste estudo, também já foi amplamente relatada por outros autores (Buergelt et al. 1978, Clarke 1997). Os aspectos cerebroide e anelado das alças intestinais são decorrentes do acentuado espessamento da parede intestinal, atribuídos à severa infiltração inflamatória transmural, principalmente em mucosa e submucosa do jejuno e íleo. Essas lesões foram observadas em vários graus de intensidade nos animais necropsiados neste trabalho, entretanto, nem sempre estão presentes e a variação na severidade destas lesões pode estar relacionada ao estágio da infecção, ao status imune do ani- mal, à susceptibilidade individual eà cepa de Map (Menendez 1990). A aparência enrugada da mucosa não desaparece quando o intestino é distendido (Chiodini et al. 1984); este achado não deve ser confundido com a alteração que ocorre logo após a morte devido à persistência do peristaltismo (Driemeier et al. 1999). O comprometimento das camadas muscular e serosa do intestino, pela extensão da infiltração inflamatória da mucosa e submucosa, esteve presente nos casos mais severos.

As estruturas "polipoides" observadas na superfície da mucosa do duodeno em duas vacas deste estudo, à histopatologia, correspondiam ao acentuado espessamento da muscular da mucosa, à hipertrofia das fibras musculares lisas da lâmina própria, à proliferação de glândulas duodenais e intestinais. No duodeno desses animais também foi possível identificar a presença de BAAR pela coloração de ZN. Nestas áreas não havia qualquer estrutura que pudesse sugerir parasitose ou outro processo patológico. É possível que a infiltração inflamatória na mucosa e submucosa intestinal tenha causado modificações estruturais e consequentes alterações proliferativas nas regiões afetadas. Acreditamos que a hipertrofia da lâmina própria e da muscular da mucosa, pouco referidas na literatura, principalmente em jejuno e íleo, presentes em variados graus de intensidade nos animais estudados, também sejam alterações secundárias ao acúmulo de células inflamatórias granulomatosas. Alterações da mucosa intestinal, observadas neste estudo, tais como aspecto polipoide em duodeno, hiperplasia de glândulas duodenais e acentuada hipertrofia da lâmina própria, não haviam sido descritos na literatura em animais com paratuberculose; estudos mais detalhados são necessários, a fim de esclarecer a patogenia dessas lesões.

É importante assinalar a presença do infiltrado linfocitário em torno e no interior dos gânglios nervosos submucosos (plexos de Meissner) e atrofia das fibras nervosas, tais infiltrados são menos frequentes nos plexos mioentéricos de Auerbach e nos feixes musculares lisos (Dacorso Filho et al. 1960, Clarke 1997); todas essas alterações foram observadas nos animais estudados. A perineurite pode estar associada à ocorrência de hipersensibilidade intestinal que contribui para a diarreia (Buergelt et al. 1978, Clarke 1997). Ao contrário do observado neste estudo, Mota et al. (2010) relataram a ocorrência de hiperplasia dos feixes do plexo nervoso de Auerbach em búfalos acometidos pela paratuberculose.

Nos demais órgãos os achados foram menos específicos, tais como mau estado corporal e atrofia serosa dos depósitos de gordura podem ser atribuídos à deficiência nutricional consequente à absorção intestinal deficiente (Buergelt et al. 1978, Clarke 1997, Driemeier et al. 1999). Placas de mineralização no endocárdio e na aorta foram também descritas por alguns autores (Buergelt et al. 1978, Driemeier et al. 1999), que igualmente, observaram áreas claras de aspecto rugoso no endocárdio e na íntima da aorta. A mineralização da íntima das artérias tem sido descrita em diversas doenças caquetizantes de bovinos tais 
como na tuberculose e na intoxicação por plantas calcinogênicas (Döbereiner et al. 1971), porém, é também considerado um achado de necropsia incidental em animais velhos (Kitt 1927 apud Driemeier et al. 1999); trata-se, portanto, de uma lesão inespecífica (Driemeier et al. 1999), não necessariamente relacionada com a inflamação granulomatosa crônica. No entanto, Buergelt et al. (1978) afirmam que são causadas por distúrbios metabólicos associados à infecção pelo Map. Hepatite granulomatosa multifocal foi relatada também por Buergelt et al. (1978) e Driemeier et al. (1999); estes autores observaram BAAR associado ao infiltrado inflamatório. Em nosso estudo, focos de infiltrado inflamatório mononuclear foram observados no fígado de dois animais (Vacas 335 e 500), porém BAAR não foram visualizados.

\section{Diagnóstico diferencial}

$\mathrm{Na}$ tuberculose, apesar do emagrecimento progressivo, em geral não se observa diarreia e há predominância de granulomas de natureza necrótico-caseosos, frequentemente mineralizados, em diversos órgãos, especialmente no pulmão (Gelberg 2007).

Diarreia crônica em bovinos adultos, embora observada com frequência nos casos graves da paratuberculose, é um sinal clínico inespecífico. Tal disfunção pode ocorrer também na deficiência de cobre condicionada ao excesso de molibdênio (Mazzocco et al. 2009, Tokarnia et al. 2010) associado com despigmentação dos pêlos ao redor dos olhos e a diminuição do apetite, sinais comumente ausentes na Doença de Johne, na qual o apetite está normal ou exacerbado, mesmo nos estágios mais avançados da infecção. Clarke (1997) descreve que na paratuberculose pode-se observar despigmentação dos pêlos, o que torna a comercialização do couro economicamente inviável; alguns animais do nosso estudo apresentaram discretas alterações na pelagem tais como aspecto áspero e opaco (Vaca 295) e áreas de alopecia na face (Vaca 493).

$\mathrm{Na}$ intoxicação por flúor, similarmente à paratuberculose, os animais apresentam diarreia intermitente, perda de peso, produção de leite diminuída e más condições gerais, no entanto observa-se também, escurecimento dos dentes e claudicação (Riet-Correa et al. 1983), sinais ausentes nos animais deste estudo.

$\mathrm{Na}$ disenteria de inverno, causada pelo coronavírus, à semelhança da paratuberculose, observa-se diarreia aquosa e afeta animais adultos, mas ocorre sob forma de surtos que perdura por aproximadamente uma semana (Radostits et al. 2000); ao contrário, da diarreia crônica e intermitente em animais com a doença de Johne.

Diarreia em animais adultos também pode ser observada na acidose lática, mas trata-se de um quadro, em geral, agudo e associado à ingestão excessiva de alimentos altamente fermentáveis. O sistema de criação do rebanho estudado era semi-intensivo, e a oferta da suplementação aos animais era controlada.

$\mathrm{Na}$ diarreia viral bovina (BVD) os animais apresentam quadro clínico semelhante ao da paratuberculose, mas a
BVD cursa com anorexia, pode ser febril, afeta animais de todas as idades e a morbidade e a letalidade em geral são altas (Jubb et al. 2007). O rebanho estudado apresentava mortalidade baixa e os animais afetados tinham, aproximadamente, cinco anos de idade.

As parasitoses gastrointestinais, apesar de cursarem com diarreia crônica, são raras em animais adultos e, quando ocorrem, fatores que causam queda de imunidade geralmente estão presentes, tais como deficiências nutricionais graves, principalmente deficiência de fósforo (Tokarnia et al. 2010). O rebanho estudado, em geral, apresentava estado nutricional bom, e os animais com sinais clínicos da paratuberculose eram vacas adultas que se alimentavam normalmente.

$\mathrm{Na}$ intoxicação por polpa cítrica e na ingestão de Vicia spp., observa-se inflamação granulomatosa em vários órgãos (Bracarense et al. 1999, Gava et al. 1999, Barros et al. 2001), enquanto que na paratuberculose a inflamação afeta principalmente intestino e linfonodos mesentéricos, e são raras ou ausentes em outros órgãos, como observado nos animais necropsiados neste estudo.

$\mathrm{Na}$ intoxicação por Brachiaria spp., apesar do quadro clínico ser diferente, foi relatada a ocorrência de macrófagos espumosos nos linfonodos (Driemeier et al. 1998), porém a coloração pelo $Z N$ resulta negativa. Animais deste estudo apresentaram infiltração por macrófagos epitelioides em córtex e medular dos linfonodos mesentéricos com presença de BAAR.

\section{CONCLUSÕES}

No estudo desse rebanho, o diagnóstico de paratuberculose foi estabelecido com base nos aspectos epidemiológicos, clínico-patológicos, no isolamento e na identificação de Mycobacterium avium subsp. paratuberculosis em amostras de fezes, raspado de mucosa intestinal e leite, através de cultivo bacteriano e PCR IS900, bem como no teste ELISA indireto.

A partir dos dados obtidos no teste sorológico observou-se que o rebanho estudado apresentava alta prevalência de animais sororreagentes.

Nos três anos de estudo, após implementação de medidas de controle, notou-se considerável diminuição da ocorrência de casos clínicos no rebanho, de seis casos por ano para somente um caso por ano.

Agradecimentos.- Ao proprietário e aos funcionários da fazenda estudada pela disponibilidade e auxílio na obtenção dos dados clínicoepidemiológicos necessários para o desenvolvimento deste estudo.

\section{REFERÊNCIAS}

Ayele W.Y., Svastova P., Roubal P., Bartos M. \& Pavlik I. 2005. Mycobacterium avium subspecies paratuberculosis cultured from locally and commercially pasteurized cow's milk in the Czech Republic. Appl. Environ. Microbiol. 71(3):1210-1214.

Barros C.S.L., Fighera R.A., Rozza D.B., Rech R.R., Sallis S.V. \& Langohr I.M. 2001. Doença granulomatosa sistêmica em bovinos no Rio Grande do Sul associada ao pastoreio de ervilhaca (Vicia spp.). Pesq. Vet. Bras. 21(4):162-171. 
Bracarense A.R.L., Reis A.C.F., Netto D.P. \& Alfieri A.A. 1999. Enterite hemorrágica em bovinos leiteiros na região de Londrina, PR, alimentados com polpa cítrica. 9ำ Encontro Nacional de Patologia Veterinária, Belo Horizonte, MG, p.127.

Buergelt C.D., Hall C., Mcentee K. \& Duncan J.R. 1978. Pathological evaluation of paratuberculosis in naturally infected cattle. Vet. Pathol. 15:196-207.

Carvalho I.A. 2008. Isolamento e detecção molecular de Mycobacterium avium subspecie paratuberculosis (Map) em rebanhos bovinos leiteiros na região de Viçosa, MG. Dissertação de Mestrado em Medicina Veterinária, Universidade de Viçosa, MG.

Chiodini R.J. 1989. Crohn's disease and the mycobacterioses: A review and comparison of two disease entities. Clin. Microbiol. Rev. 2:90-117.

Chiodini R.J., Van Kruiningen H.J. \& Merkal R.S. 1984. Ruminant paratuberculosis (Johne's disease): The current status and future prospects. Cornell Vet. 74:218-262.

Clarke C.J. 1997. The pathology and patogenesis of paratuberculosis in ruminants and other species. J. Comp. Pathol. 116: 217-261.

COBEA 1979. Colégio Brasileiro de Experimentação Animal, Lei nº. 6.638, 8 de maio de 1979.

Collins M.T. 1996. Diagnosis of paratuberculosis. Vet. Clin. North Am., Food Anim. Pract. 12:357-371.

Collins M.T., Wells S.J., Petrini K.R., Collins J.E., Schultz R.D. \& Whitlock R.H. 2005. Evaluation of five antibodies detection tests for diagnosis of bovine paratuberculosis. Clin. Diagn. Lab. Immunol. 12(6):685-692.

Dacorso Filho P., Campos I.O.N., Faria J.F. \& Langenegger J. 1960. Doença de Johne (paratuberculose) em bovinos nacionais. Arqs Inst. Biol. Anim., Rio de J., 3:129-139.

Döbereiner J., Tokarnia C.H., Costa J.B.D., Campos J.L.F. \& Dayrell M.S. 1971. "Espichamento", intoxicação de bovinos por Solanum malacoxylon, no Pantanal de Mato Grosso. Pesq. Agropec. Bras. 6:91-117.

Driemeier D., Barros S.S., Peixoto P.V., Tokarnia C.H., Döbereiner J. \& Brito M.F. 1998. Estudo histológico, histoquímico e ultra-estrutural de fígado e linfonodos de bovinos com presença de macrófagos espumosos ("foam cells"). Pesq. Vet. Bras. 18(1):29-34 .

Driemeier D., Cruz C.E.F., Gomes M.J.P., Corbellini L.G., Loretti A.P. \& Colodel E.M. 1999. Aspectos clínicos e patológicos da paratuberculose em bovinos no Rio Grande do Sul. Pesq. Vet. Bras. 19(3/ 4):109-115.

Ferreira R., Fonseca L.S. \& Lilenbaum W. 2001. Detecção de anticorpos contra Mycobacterium paratuberculosis em rebanhos bovinos do Estado do Rio de Janeiro, Brasil. Revta Bras. Med. Vet. 23(4):19-24.

Ferreira R., Ristow P., Marassi C.D., Rocha F., Oelemann W.M.R., Rodrigues A.B.F., Santos A.S.O., Carvalho E.C.Q., Carvalho C.B., Fonseca L.S. \& Lilenbaum W. 2003. Paratuberculose bovina em fazenda de produção leiteira em Resende, Rio de Janeiro, Brasil. 22을 Congresso Brasileiro de Microbiologia, Florianópolis, SC. (CD-Rom)

Fonseca L.F.L., Olival A.A., Pereira C.C., Heinemann M.B., Richtzenhaim L.J. \& Santos M.V. 2000. Identificação de anticorpos anti-Mycobacterium paratuberculosis em rebanhos bovinos leiteiros do Estado de São Paulo. Arqs Fac. Vet. UFRGS, Porto Alegre, 28:51-56.

Gava A., Barros C.S.L., Sousa R.S. \& Traverso S.D. 1999. Polpa cítrica como causa de mortalidade em bovinos no Brasil. 9ำ Encontro Nacional de Patologia Veterinária, Belo Horizonte, MG, p.76.

Gelberg H.B. 2007. Alimentary system, p.301-391. In: McGavin M.D. \& Zachary J.F. (Eds), Pathologic Basis of Veterinary Disease. $4^{\text {th }}$ ed. Mosby Elsevier, St. Louis.

Gomes M.J.P., Driemeier D., Ribeiro V.R., Wunder Jr E.A., Asanome W., Lanzon L.F. \& Wald V.B. 2002. Doença de Johne: isolamento do Mycobacterium avium subsp. paratuberculosis (Map) em um rebanho leiteiro infectado na região sul do Brasil. Act. Scient. Vet. 30(2):113-118.
Hagan W.A. 1938. Age as factor in susceptibility to Johne's disase. Cornell Vet. 28:34-40.

Hermon-Taylor J. \& Bull T.J. 2002. Crohn's disease caused by Mycobacterium avium subsp. paratuberculosis: A public health tragedy whose resolution is long overdue. J. Med. Microbiol. 5:3-6.

Johnson-Ifearulundu Y.J. \& Kaneene J.B. 1997. Epidemiology and economic impact of subclinical Johne's disease: A review. Vet. Bull. 67(6):437-447.

Jubb K.V.F., Kennedy P.C. \& Palmer N.C. 2007. Pathology of Domestic Animals. Vol.2. $5^{\text {th }}$ ed. Saunders Elsevier, Edinbourgh.

Kitt T. 1927. Lehrbuch der Pathologischen Anatomie der Haustiere. Ferdinand Enke, Stuttgart, p.695. (Apud Driemeier et al. 1999)

Manning E.J. \& Collins M.T. 2001. Mycobacterium avium subsp. paratuberculosis: Pathogen, pathogenesis and diagnosis. Rev. Sci. Tech. OIE 20:133-150

Mazzocco M.B., Furlan F.H., Souza S.F., Froehlich D.L., Traverso S.D. \& Gava A. 2009. Molibdenose em bovinos no estado de Santa Catarina. $14^{\circ}$ Encontro Nacional de Patologia Veterinária, Águas de Lindóia, SP. (CD-Rom)

Menendez L.A.C. 1990. Ovis: tratado de patologia y produccion ovina. Luzán 5, Madrid, p.39-47.

Mota R.A., Pinheiro Jr J.W., Gomes M.J.P., Peixoto R.M., Maia F.C.L., Brito M.F., Chies J.A.B., Snel G.G.M., Bercht B.S. \& Juffo G.D. 2007. Paratuberculose em um rebanho leiteiro no Estado de Pernambuco, PE. Arqs Inst. Biológico, São Paulo 74(2):73-79.

Mota R.A., Peixoto P.V., Yamasaki E.M., Medeiros E.S, Costa M.M., Peixoto R.M. \& Brito M.F. 2010. Ocorrência de paratuberculose em búfalos (Bubalis bubalis) em Pernambuco. Pesq. Vet. Bras. 30(3):237-2432.

Radostits O.M., Gay C.C., Blood D.C. \& Hinchcliff K.W. 2000. Clínica Veterinária: um tratado de doenças dos bovinos, ovinos, suínos, caprinos e equinos. 9 ${ }^{a}$ ed. Guanabara Koogan, Rio de Janeiro. 1737p.

Riet-Correa F., Oliveira J.A., Mendez M.C. \& Schild A.L. 1983. Poluição ambiental como causa de intoxicação por flúor em bovinos no município de Rio Grande, Rio Grande do Sul. Pesq. Vet. Bras. 3(4):107-114.

Rivera F.E.B. 1996. Levantamento sorológico utilizando-se a técnica ELISA em rebanhos apresentando problemas reprodutivos. I. Enterite paratuberculose. Encontro de Laboratórios de Diagnóstico Veterinário do Cone Sul, Campo Grande, MS, p.20-22.

Sherman D.M. 1985. Current concepts in Johne's disease. Vet. Med. Small Anim. Clin. 8:77-84.

Stabel J.R. 1997. An improved method for cultivation of Mycobacterium paratuberculosis from bovine fecal samples and comparison to three other methods. J. Vet. Diag. Invest. 9:375-380.

Sweeney R.W. 1996. Transmission of paratuberculosis. Vet. Clin. North Am., Food Anim. Pract. 12(12):305-312.

Tokarnia C.M.H., Peixoto P.V., Barbosa J.D., Brito M.F. \& Döbereiner J. 2010. Deficiências Minerais em Animais de Produção. Editora Helianthus, Rio de Janeiro. 191p.

Whitlock R.H \& Buergelt C. 1996. Preclinical e clinical manifestations of paratuberculosis (including pathology). Vet. Clin. North Am., Food Anim. Pract. 12(2):345-357.

Whitlock R.H., Weels S.J., Sweeney R.W. \& Van Tiem J. 2000. ELISA and fecal culture for paratubeculosis (Johne's disease): Sensitivity and specificity of each method. Vet. Microbiol. 77:387-398.

Whittington R.J., Marsh I., Turner M.J., McAllister S., Choy E., Eamens G.J., Marshall D.J. \& Ottaway S. 1998. Rapid detection of Mycobacterium paratuberculosis in clinical samples from ruminants and in spike environmental samples by modified BACTEC 12B radiometric culture and direct confirmation by IS900 PCR. J. Clin. Microbiol. 36(3):701707. 